\title{
IMPLICATIONS OF THE COVID-19 PANDEMIC
}

\author{
Ioan Mircea PAȘCU, PhD \\ Professor, National University of Political Studies and Public Administration \\ Bucharest/ Romania
}

Alexandra NUNWEILLER-BĂLĂNESCU, PhD candidate

National University of Political Studies and Public Administration

Bucharest/ Romania

\begin{abstract}
The global order was facing multiple challenges even before the pandemic, so it is very likely - based on the evolutions recorded since the beginning of 2020 that these challenges will further amplify. On the impact of COVID-19 on the world order, opinions of political scientists vary greatly, from reserved optimism to worst-case scenario, from treating it as a simple inflexion point to forecasting the transformative changes it will entail. In this article we argue that this current pandemic will only accelerate previous trends by deepening international power competition, thus accelerating the transition towards a more realist world order. This working hypothesis disregards potential non-linear events that might occur from this point on and that could impact all forecasts ${ }^{1}$. In this article we discuss the structure of the current international system and we analyse recent developments, thus trying to determine which specific trends
\end{abstract}

1 Doran (1999) considers that the main reason forecasts fail - especially in the international relations field, whose track record in forecasting is far from being the most accurate - is because no technique has been developed that allows the forecaster to predict, prior to the event itself, when a nonlinearity will occur. A nonlinearity is defined as a critical point at which expectations (predictions) induced by the prior trend suddenly confront a profound alteration in that trend, indeed, an abrupt inversion. A nonlinearity is a total break from the past trend, a discontinuity. 
will be accelerated. Furthermore, we examine the "lessons" learned so far and try to determine what can be done to limit the consequences of the pandemic, at least at the national level.

Keywords: COVID-19; world order; multilateralism; democracy; US; EU; China; Romania.

\section{THE INTERNATIONAL CONTEXT}

For several years it has become clear that the current world order ${ }^{1}$, resulting at the end of World War II and based on multilateralism, has begun to rapidly deplete its resources. Consequently, the feeling that the "game" is coming to an end and the "players" are exhausting their "cards", which requires a "reshuffling" for the start of a new "game", is gaining more and more momentum. It is argued that this order was destined to fail from the start, as it contained the seeds of its own destruction mainly because it required all liberal states in the system to pursue a highly revisionist and wildly ambitious policy of regime change and because it required a deep hyperglobalization that ultimately caused major economic and political problems inside the liberal democracies (Mearsheimer 2019).

Usually, such a reshuffling of "cards" and the beginning of a new "game" took place either through a major economic crisis or a war, both phenomena that overturned the hierarchy of great powers and affected the institutional architecture of the international order that existed until then. If, similarly to what happened between 1929-1933, the international system already faced a financial crisis (in 2008), this time it was not followed - yet, at least - by a war, as it did in the 1930'. However, the current COVID-19 pandemic has even wider consequences than a war: if in the case of both world wars, it took years before

1 Defined by Mearsheimer $(2019,9)$ as "an organized group of international institutions that help govern the interactions among the member states, which is created and managed by the great power(s)". 
they truly engaged a large enough number of actors to be called world wars (while entire areas of the planet still remained unaffected), this time the effect was almost instantaneous and its consequences are global from the start, facilitated by the very phenomenon of globalization (which is now itself under question).

It is worth noting that, for most of human history, plagues and pandemics have had significant effects (Drezner 2020,5) on political strategy and sometimes they even led to the downfall of empires ${ }^{1}$, despite being far less studied than other types of crises. It is true that economic crises and wars do happen more often than global pandemics and their effects are much more easily traceable in a cause-effect logic. But it is also true that the more interconnected and open the world is, the more it is prone to pandemics and the more it is vulnerable to its effects, while no individual state can shut itself completely from the others to try to manage the crisis alone.

\section{TRENDS IN THE INTERNATIONAL SYSTEM}

COVID-19 is affecting relations between states, in many cases, for the worse (Wang 2020, 2). While it is too early to tell what the crisis means for the future of international relations, based on the evolutions of the last months, it seems likely that the pandemic will continue to accelerate the trends that already shaped international relations in the previous years.

For several years, primarily as a result of the actions of the United States (initially the main architect of the postwar world order based on multilateralism), a new paradigm based on unilateralism has begun to prevail in international affairs. In fact, the new US National Security Strategy (December 2017) declared that the main feature of the international system is already the deepening of great power competition, with China becoming the main potential

1 One of such first accounts comes from Thucydides and his analyses on the plague's effects on Ancient Greece strategy and its eventual decline. 
opponent. The COVID-19 pandemic, which affected both major competitors, is a catalyst for the disputes between the two superpowers, as well as an element of fracture in the model of interaction between them, but also between the other powers. If Europe attempts to stay on the sidelines of the Sino-American rivalry, it will mean the end of NATO (as it will become irrelevant to the new competition) and Europe's nations will be forced to assume full responsibility for their own defense (Walt 2020, 18). Even though transatlantic relations were strained in the last 4 years, it now seems that Europe will more eagerly take Washington's side (especially after Biden's victory in the presidential elections), although it is very difficult to predict what the future holds, especially during a crisis. However, if Europe would remain on the sidelines, great power competition between the US and China will intensify even further (as they are not discouraged by the other's allies) without Europe being ready to play at the "big chess board" yet.

International organizations have lacked the resources and authority to lead effective responses and support vulnerable countries, while various controls by states were enacted in a haphazard, unilateral way that impaired their effectiveness and added to discord (Wang 2020,8), providing a further blow to global governance and multilateralism.

Authoritarian governments were enjoying a remarkable comeback even before the pandemic began: according to Freedom House, 2019 was the 14th consecutive year in which global freedom declined, and in 2017 the Economist magazine's annual Democracy Index downgraded the United States from the status of "full" to "flawed" democracy (Walt 2020, 8). COVID-19 is strengthening these trends as well, at least in the short-term, as a direct result of the measures adopted by governments all around the globe (greater surveillance of their population, restrictions of movement, travel bans, etc.) with no clear end in sight. While democracies have been thought to be better able to detect and respond to famines, pandemics, and other public health crises, largely because information tends to travel faster in open societies and leaders who are accountable to the public have greater incentives to respond quickly (Ben-Ami 2020), in the context of COVID-19 things are less clear. According to Rachel Kleinfeld of the Carnegie Endowment "the record (as of March 2020) does not 
show a strong correlation between efficacy and regime type" (Kleinfeld 2020), which poses some serious concern. If democracy is being sacrificed by the need for increasing control motivated by the pandemic states that adopt authoritarian type of policies question its utility even more.

Given that the prevention of the resurgence of the COVID-19 pandemic (multiples waves) and the prevention of a recurrence of such a situation in general is becoming the main concern of states throughout the international system, there are arguments that support, on the one hand, a decrease in the importance of the military factor, and on the other hand, an increase in its importance. Just as in the spring of 1918 the German Imperial Army had to cancel the third phase of the offensive against the Allies due to the Spanish flu, now there are reports of a decline in military production, for example, in Russia, due to the effects of the pandemic as it is facing internal public health and political problems. But the pandemic has also impacted the Allies, as NATO's readiness weakened due to restricted exercises and troop mobility (Cimmino, Kroenig and Pavel 2020,3). While the entrenched views of what constitutes a threat to national security are often skewed toward military threats such as weapons of mass destruction, this pandemic is also a reminder that health security is critical to national security and, in the aftermath of COVID-19, it may do well for countries to bring health security - the freedom from diseases and access for all to primary healthcare-back to mainstream national security thinking (Caballero-Anthony 2020, 42-43). Furthermore, the COVID-19 crisis gives a real-life sense of what bioterrorism could look like and from that there are lessons to be learned for any defence institution (Tardy 2020, 20).

It also important not to neglect the possibility that the authorities in one country or another, faced with an inability to manage the pandemic domestically, will knowingly cause an international crisis in order to divert attention from the mismanagement of the pandemic towards an "external threat". Furthermore, in the absence of an outside enemy, in some countries the narrative has aimed to reconstruct a state-based threat by linking the origin of the virus to a foreign country (Tardy 2020,14), which can have serious consequences for the stability of the international order. 
Beyond the aspects of the military interaction between the great powers, the economic consequences of the pandemic are instinctively perceived as major, despite the fact that no one knows exactly what they will be and what differentiated impact they will have on the great powers. For example, the relocation of Chinese production back to the countries of origin - which started shortly after the crises emerged - is an increasingly prevalent phenomenon (although still limited to certain sectors). This creates, at least in the short term, difficulties for the Chinese economy, and in the medium and long term it might generate a reorientation towards the internal market. China's economy contracted for the first time in almost half a century, shrinking by 6.8 percent in the first quarter of 2020 (McDonald 2020) and while China is prepared to inject trillions of yuan into the economy, Chinese officials will have to lower growth expectations for 2020 (Yao 2020). Russia and the US also have economic difficulties caused by the pandemic. US's stock markets are highly volatile, while unemployment is sky-rocketing, leaving the country vulnerable to a recession. The drastic drop in oil prices also widows Russia's economy substantially from its main source of external income, with a negative impact, including on its ambitions for military power.

Recent years have seen a rise in anti-globalization sentiment and push back against the cross-border flow of goods, capital and people, primarily in industrialized countries (Wang 2020, 5). COVID-19 seems to reinforce these tendencies. Economic globalization as we know it seems to have stopped, and may even reverse. Given that even the "exit" from the pandemic is differentiated, both exports, which will have to be absorbed by the domestic market, and imports, which will have to be replaced by domestic production, will suffer. Under these conditions, it can be anticipated that most countries will seek to reduce their external dependence, satisfying as much as possible of their needs from domestic production, while at the same time expecting increased barriers to their exports. Inevitably, pre-pandemic flows of international trade will change significantly. This will have a direct impact on states' revenues and on their relative positions in the international hierarchy (just to make up for these losses, Germany has decided to directly support the economies of its main EU trading partners). While COVID-19 weakens some aspects of economic 
globalization, the pandemic shows that "ecological globalization" 1 is only getting stronger and regardless of what happens to the various vectors of economic integration, the growing effects of ecological globalization mean that the fates of different countries are deeply entwined (Wang 2020, 2-7).

Overall, starting from the thesis that, from 2021 onwards, we can expect the intensification of efforts to define a new world order, based much less on multilateralism, and more and more on unilateralism, in which joint action will be focused almost totally on the management of the pandemic and its effects, we will have to prepare to face a world much more selfish than it has been until now, in which the best friend of each state will be... that state itself.

In short, the post-COVID-19, the world will be less open, less free, less prosperous, and more competitive than the world many people were expecting only a few years ago (Walt 2020,3). The upside is that this crisis is still ongoing and the die are still rolling - there are still choices to be made (one, for example, will have to do with the vaccine distribution), so the level of intensity of the competition is still uncertain and some consequences can still be mitigated, although the general trends are very difficult to reverse at this point.

\section{COVID-19 and Europe's future}

As far as the European Union is concerned, we must note that it appears that it has failed the most important test - that of solidarity - which underlies its own raison d'être. Initially the EU only managed to act too little too late, preferring to witness the individual action of the Member States. We must also note EU's limited prerogatives in the public health sector (as it remains under the jurisdiction of Member States) and its relatively heavy bureaucracy (which always seem to be on the brink of failure in cases of crises and emergencies), but also members state's unwillingness to fully cooperate and coordinate while

${ }^{1}$ Ecological globalization refers to interdependence resulting from physical or biological processes, such as climate change, marine pollution, and pandemics. 
closing borders and prohibiting exports of medical supplies even to other member states, such as Italy, which was in a dire situation in March 2020. In this context, China and Russia stepped in by sending medical supplies (some of which indeed proved to be sub-standard), but this proved their intention to acquire more soft power and even their ambition to be seen as an alternative to EU's apparent unresponsiveness. One survey showed that only a fifth of Italians think EU membership benefits Italy, while two-thirds believe membership is a disadvantage (Rough 2020). A more recent poll found a plurality of Italians thinking that the country should look more to China than the United States when developing alliances outside of Europe (Bechis 2020). While Europe seems to be stepping up its game during this crisis and even if these negative trends are difficult to fully reverse once the damage has been done, Europe can still "recover" on some of the issues especially if it manages to limit the impact of the economic crisis that will most likely follow this pandemic.

The security and defence policy of the European Union is also impacted by the COVID-19 crisis. Important differences from the previous Commission's priorities became evident even before the pandemic: for example, the European Defense Fund was halved in the budget proposal for the next financial framework 2021-2027, and funds for military mobility, one of the pillars of NATO cooperation - especially important for Central and Eastern European states - were significantly reduced. As anticipated, the next multiannual financial framework will focus on helping the EU rebuild after the COVID-19 pandemic and on supporting investment in the green and digital transitions, while the smallest share of the "big pie" (13.2 billion Euros) is earmarked for resilience, security and defence (European Council, 2020).

Beyond sacrificing defense to manage the new challenges posed by and following the pandemic, the sector of public health - a strictly national prerogative - is a major goal of the next financial framework. In this regard, we believe that the beginning of a process of integration of national health systems, following the model of "security and home affairs", should be initiated as soon as possible (even if a major obstacle will be the lack of solidarity during the pandemic). This ambition was also expressed by the President of the European Commission, Ursula von der Leyen, during her 2020 State of the Union Address: 
„For me, it is crystal clear - we need to build a stronger European Health Union".

\section{THE GEO-STRATEGIC CONTEXT OF ROMANIA}

Although it is more than desirable for Romania to be involved from now on in shaping the parameters of the new world order, we must be aware that a middle-sized country is not allowed in the turf of grand politics, except when its geographical area comes to the attention of the great powers.

Multiple examples in Romania's history fully prove this reality, the most recent being that of its relevance in Afghanistan and Iraq: as long as the conflicts were ongoing, the logistical contribution of Romania was needed, but once they have either ended (Iraq) or are about to (with the withdrawal of American forces from Afghanistan), Romania's strategic relevance has diminished accordingly. It is also true that, through the illegal annexation of Crimea and the military destabilization of eastern Ukraine that followed, Romania's strategic relevance has partially bounced back. As a result of the pandemic (but not exclusively), it is possible that these developments will not be enough to maintain US's attention to Eastern Europe at the same level, especially given that, even officially, China has overtaken Russia as a focal point of US attention. Of course, this does not mean an abandonment by the United States, but rather an incentive for Romania to maintain its relevance, establishing the connection with the Middle East, an area that will undoubtedly continue to attract the attention of the great powers. Romania's new defence strategy (published in July 2020) highlights this ambition to strengthen its profile as a relevant international actor (in partnerships with its allies) by also strengthening cooperation with Middle Eastern countries and states involved in the region, with a view to making its own contribution to resolving the multiple crisis in the Middle East. 


\section{THE INTERNAL CONTEXT. RECOMMENDATIONS FOR ROMANIA}

The crisis caused by COVID-19 caught the world unprepared to handle it, which doesn't come as much as a surprise since this pandemic can be considered a black swan type event - low probability, high impact. But the crisis is not just about the specific aspects of this pandemic - the speed and extent of the infection, the number of fatalities, the specific treatment needed or the distribution of the vaccine - but also about the vulnerabilities of the state's health systems, emergency management, administration, education, etc., which were forcefully brought into the spotlight. In this section we will focus on Romania's handling of the pandemic and the lessons we can learn from it (to strengthen internal, as well as external resilience), while some of them can also be applicable to other states.

The central idea is that the authorities need to make a serious analysis of these systems and how they have worked, correcting the shortcomings based on the lessons of the pandemic. This is imperative as we now have to expect similar situations to recur in the near or more distant future, which will exacerbate existing inequalities, both internationally and nationally. If these vulnerabilities seem easier to identify for the health system, due to the visibility gained during the pandemic, in terms of the crisis management system itself, it must be analysed from top to bottom, aiming at ensuring cohesion and efficiency, so that its actions no longer bear the imprint of improvisation, competition between components and a questionable legitimacy. In this context, the focus will have to be on the provision of the necessary reserves of medical supplies, which requires a special attention on the state reserve system, while the authorities will have to set up adequate national storage facilities and stop renting them from private entities, as they do now. Romania will have to evaluate the role of the Military in such circumstances, capitalizing on the recognized qualities of the military system - organization, equipment, command unit, coherence and discipline - to allow it to assume a proper role in such situations, along with its traditional missions. 
Of course, one of the most important areas where urgent action is needed is the economy, which needs to be put back into operation urgently in order to quickly compensate for the months of inactivity and related losses in parallel with supporting the most affected sectors - tourism, transport, services in general, etc. Under the (ongoing) given conditions, the Romanian economy will have to rely increasingly, from now on, on the domestic market, whose absorption capacity of domestic production will have to be amplified accordingly.

The authorities must not lose sight of a major difference between the current crisis and that of 2008-2010: if the latter endangered the big banks firstly, the former endangers especially small businesses, which, in the case of the Romanian economy (without major companies), will amplify the magnitude of the crisis we are in. It is unfortunate that the measures taken by the authorities continue to negatively impact mostly small businesses, which have such a high share in the national economy as a whole.

To adequately address this health crisis and its consequences it is necessary to develop and rigorously implement an investment strategy that focuses on healthcare, including research (in which Romania has a long tradition), the pharmaceutical industry and education (especially the improvement of online teaching and evaluation systems). The latter will help us reduce our external dependencies and capitalize on the national creative potential, opening new venues for export and, through this, for international recognition.

Another element that will certainly affect the magnitude and speed of the recovery from this crisis, and which makes economists hesitant, is the impact of the psychological factor on the economic behavior of consumers ${ }^{1}$. The impact of this factor is difficult to assess for now and more time needs to pass for it to be fully completely evaluated and eventually corrected, also due to the fact that the current crisis was amplified by panic. So far, people have been more careful to spend and more inclined to save (about $46 \%$ of Romanians responding to a ING survey $^{2}$ said that they spent less money during the isolation period, above the

${ }^{1}$ For a detailed analysis of this phenomenon, see Seema Mehta, Tanjul Saxena and Neetu Purohit 2020.

2 Published in July 2020 by Profit.ro. 
European average of $44 \%$ ), while a general shift in consumer sentiment has been observed world-wide, from a consumerist behaviour towards a more needinduced one (Mehta, Saxena and Purohit 2020, 297). These two factors, together with the impoverishment of large masses of unemployed citizens, will imperil the functioning of the internal market as an engine of economic recovery.

Overall, Romania will have to - if it wants to enhance its resilience and secure a better place in the new world order - to identify and amplify its comparative advantages. In this process, authorities will also have to re-evaluate abandoned industries and resume discontinued production.

Increased attention (not only from a political point of view) must be paid to those returning from the diaspora, as a large part of them worked in sectors tourism, services - which will continue to suffer in the countries where they came from, having to be absorbed by the national labour market. In ensuring this, the initiation of large infrastructure projects, supported by the state, is a frequently used way in such situations.

Last but not least, agriculture must be re-prioritized: food security is of the outmost importance. Attention will have to be paid to both large and small producers, which will have to be subsidized, and not just from EU funds. Collecting centers will have to be created for small producers, which should be connected to both the manufacturing industry and directly to consumers, including through supermarket chains. In this context, agricultural research will need to be properly revigorated and supported.

Of course, all these objectives require financial support, even massive, given that state resources are inevitably diminished as a direct result of "locking down" the economy. External financial assistance, especially after the recent downgrading of Romania's credit rating, will become more difficult/expensive to obtain. Romania will have to rely more and more on its own resources, or, in order to stimulate them, a change of approach form the part of the state financial authorities is needed. Revenue does not come faster from over-taxation or the imposition or heavy fines, but rather from lower taxation and the granting of tax incentives. 


\section{ACKNOWLEDGEMENT}

We appreciate the research undertaken by SNSPA alumni Bizdrigheanu BiancaTania, Vasile Crețu, Frățila Ecaterina and Tănase Valentina during their practice at the Center for Strategic Studies that proved valuable for this article.

\section{REFERENCES}

- Bechis, Francesco. 2020. "Polls show concerning effect of Chinese coronavirus charm offensive in Italy". Atlantic Council, April 17. https://www.atlanticcouncil.org/blogs/new-atlanticist/polls-showconcerning-effect-of-chinese-coronavirus-charm-offensive-in-italy/ .

- Ben-Ami, Shlomo. 2020. "Democracies are Better at Managing Crises". Project Syndicate, May 19. https://www.projectsyndicate.org/commentary/democracy-or-autocracy-better-during-crisisby-shlomo-ben-ami-2020-05?barrier=accesspaylog .

- Caballero-Anthony, Mely. 2020. "COVID-19 and Global Governance: Waking Up to a Safe New World in Challenges of Global Governance Amid the COVID-19 Pandemic". In Challenges of Global Governance Amid the COVID-19 Pandemic, 42-45. Council on Foreign Relations: New York.

- Cimmino, Jeffrey, Matthew Kroenig and Barry Pavel. 2020. "Taking Stock: Where Are Geopolitics Headed in the COVID-19 Era?". Paper, Atlantic Council Strategy Papers. https://www.atlanticcouncil.org/wpcontent/uploads/2020/06/Taking-Stock-Where-Are-Geopolitics-Headedin-the-COVID-19-Era.pdf .

- Doran, Charles F. 1999. "Why Forecasts Fail: The Limits and Potential of Forecasting in International Relations and Economics". Prospects for International Relations: Conjectures about the Next Millennium (Summer, 1999), Vol. 1, No. 2: 11-41. 
- Drezner, Daniel W. 2020. "The Song Remains the Same: International Relations After COVID-19". International Organization 74, Supplement 2020: 1-18.

- European Council, 2020. "Infographic - EU budget 2021-2027 and recovery plan". https://www.consilium.europa.eu/en/infographics/recovery-planmff-2021-2027/\# .

- Infographic - EU budget 2021-2027 and recovery plan. 2020. https://www.consilium.europa.eu/en/infographics/recovery-plan-mff2021-2027/.

- Kleinfeld, Rachel. 2020. “Do Authoritarian or Democratic Countries Handle Pandemics Better?". Carnegie Endowment for International Peace, March 31. https://carnegieendowment.org/2020/03/31/doauthoritarian-ordemocratic-countries-handle-pandemics-better-pub-81404 .

- McDonald, Joe. 2020. "China's economy in worst downturn since '60s in virus battle". Associated Press, April 17. https://apnews.com/article/7cfa063b58a160f94235f35ab614329f .

- Mearsheimer, John J. 2019. "Bound to fail. The rise and fall of the liberal international order". International Security, Vol. 43, No. 4 (Spring 2019): 750 .

- National Security Strategy of the United States of America. 2017. https://www.whitehouse.gov/wp-content/uploads/2017/12/NSS-Final12-18-2017-0905.pdf .

- Mehta, Seema, Tanjul Saxena and Neetu Purohit. 2020. „The New Consumer Behaviour Paradigm amid COVID-19: Permanent or Transient?". Journal of Health Management, 22(2), 291-301.

- Profit.ro. 2020. "În pandemie, 4 din 10 români respondenți unui sondaj șiau redus cheltuielile și 3 din 10 au economisit mai mult". https://www.profit.ro/profitul-tau/in-pandemie-4-din-10-romanirespondenti-unui-sondaj-si-au-redus-cheltuielile-si-3-din-10-au-economisitmai-mult-19409208 .

- Rough, Peter. 2020. "How China is Exploiting the Coronavirus to Weaken Democracies". Foreign Policy, March 25. 
https://foreignpolicy.com/2020/03/25/china-coronavirus-propagandaweakens-western-democracies/

- State of the Union. 2020. https://ec.europa.eu/commission/presscorner/detail/en/SPEECH_20_16 55.

- Tardy, Thierry. 2020. "COVID-19: shaping future threats and security policies", in NATO in the Age of Pandemics, edited by Thierry Tardy, 13-20, NATO Defence College.

- Strategia Națională de Apărare a Țării. 2020. https://www.presidency.ro/files/userfiles/Documente/Strategia_Nationa la_de_Aparare_a_Tarii_2020_2024.pdf .

- Walt, Stephen M. 2020. “The Global Order After Covid-19”. Vienna: Paper, Institut für Sicherheitspolitik.

- Wang, Huiyao. 2020. "How Covid-19 Will Reinforce Trends Shaping the International Order". Vienna: Paper, Institut für Sicherheitspolitik.

- Yao, Kevin. 2020. "Exclusive: China to ramp up spending to revive economy, could cut growth target - sources". Reuters. March 19. https://www.reuters.com/article/us-china-economy-stimulusexclusive/exclusive-china-to-ramp-up-spending-to-revive-economy-couldcut-growth-target-sources-idUSKBN2161NW 